\title{
NEUTROPENIA AND THROMBOCYTOPENIA IN A PATIENT USED ISOTRETINOIN FOR ACNE VULGARIS
}

\author{
Mesut GARIPARDIÇ ${ }^{1}$ Sezai ŞAŞMAZ ${ }^{2}$ Şeref OLGAR ${ }^{3}$ Ekrem GÜLER $^{3}$
}

${ }^{1}$ Department of Pediatrics, Medical Faculty of YYU, Van, ${ }^{2}$ Department of Dermatology, Medical Faculty of Balikesir University,, Balikesir, ${ }^{3}$ Department of Pediatrics, Medical Faculty of KSU, Kahramanmaras, Türkiye

Yazışma Adresi:

Sezai ŞAŞMAZ

Balıkesir Tıp Fakültesi Dermatoloji AD, Çağış

Yerleşkesi, 10145 Balıkesir - Türkiye

E posta: drsasmaz@gmail.com

Kabul Tarihi: 02 Mart 2013

Balıkesir Sağlık Bilimleri Dergisi

ISSN: 2146-9601

e-ISSN: 2147-2238

bsbd@balikesir.edu.tr www.bau-sbdergisi.com
To the Editor,

Isotretinoin is a drug which frequently used for the treatment of moderate to severe acne. However, it has a lot of side effects, and most of them are related in skin findings. In this case report bicytopenia development in a 15 year old male patient due to isotretinoin presented. The patient had been brought to the pediatric outpatient clinic suffering from weakness, dizziness, headache and an abdominal pain complaint for 5 days. In a private hospital antibiotics and analgesic therapy had been applied, however the patient has been referred to our hospital due to bicytopenia establishment. On his physical examination, he had fever, cheilitis and oropharyngeal hyperemia. From his medical history, we have learned that he had been taking pills containing $40 \mathrm{mg} / \mathrm{d}$ isotretinoin for 45 days for his acne, and he denied other medications. On his laboratory investigation, his white blood cell count was $2500 / \mathrm{mm}^{3}$, absolute neutrophil count was $1200 / \mathrm{mm} 3$ and his thrombocyte was $81000 / \mathrm{mm}^{3}$. In addition to these his AST was $114 \mathrm{IU} / \mathrm{L}$, ALT was $119 \mathrm{IU} / \mathrm{L}$ ), ferritin levels was above $1500 \mathrm{ng} / \mathrm{dl}$, CPK was 450, LDH 576, CRP $125 \mathrm{mg} / \mathrm{dL}$ and erythrocyte sedimentation rate was $18 \mathrm{~mm} / \mathrm{h}$. On the bone marrow examination, no malignity finding but it was hypocellular and myeloid, megakaryocytic precursors were diminished. However, the eosinophilic cell precursor and erythroid precursor relatively has been increased. The viral (Ebstein-Barr virus, Cytomegalovirus, Parvovirus, HIV, Hepatitis A, B, and C), bacterial (Salmonella, Brucella), and parasitic investigation results were normal. Patient's complaints may be due to the use isotretinoin was evaluated and the medication has been stopped and after four days the bicytopenia improved to normal limits. However, the other laboratory findings (liver function, LDH, ferritin, CPK) improved at the end of second week of medication interruption.

Isotretinoin is effective against all of the etiopathological factors of acne. ${ }^{1}$ The drug act as an anti-inflammatory drug and inhibit the motility of neutrophils and eosinophils and their migration into the epidermis, decrease DNA synthesis of human lymphocytes by blocking their response to lectins and stimulate Langerhans cells, monocytes and macrophages. ${ }^{2}$ However, it has multiple side effects. The most common known isotretinoin complications are dryness of skin, lips and mucous membranes, cheilitis, itch, skin fragility, skin peeling, rash, epistaxis, dry eyes, diffuse alopecia, hyperlipidemia, raised liver enzymes, headaches, myalgia and/or arthralgia, back pain. In addition to these, the rarely reported side effects are impaired night vision, cataracts, optic neuritis, menstrual disturbances, inflammatory bowel 
disease, pancreatitis, hepatitis, corneal opacity, idiopathic intracranial hypertension, skeletal hyperostosis, extraosseous calcification, psychosis, raised blood glucose level, increased erythrocyte sedimentation rate and fatigue. $^{3-5}$ In our patient has cheilitis, myalgia, arthralgia, hepatitis and all complaints were improved after medication stopped. However, our patient has bicytopenia related findings.

Retinoids are commonly using for cancer therapy and we thought our patient's findings due to isotretinoin use. Because, retinoids are derivatives of vitamin $A$ and high levels of vitamin A derivatives can cause arrest of cell growth and morphologic differentiation of human cell lines. ${ }^{6,7}$ In Norris study, ${ }^{8}$ the effect of oral isotretinoin on in vivo chemotactic responses was studied longitudinally in 7 patients with cystic acne. As measured in a microchamber chemotaxis assay, both monocyte and neutrophil chemotaxis were inhibited 98\% during isotretinoin treatment. Moreover, they showed that in vivo chemotactic responses returned to normal within 2 months of cessation of treatment. In addition, in vitro chemotactic responses of neutrophils and monocytes from patients on isotretinoin were not diminished. So, they claim that isotretinoin produces significant anti-inflammatory effects by inhibition of monocyte and neutrophil chemotaxis across intact biologic barriers in vivo. In our case, we believed that isotretinoin use caused of both myeloid and thrombocytic cell differentiation interruption. In literature, agranulocytosis has been described due to isotretinoin use by idiosyncratic reaction, but two cell line affecting was not reported. ${ }^{9-11}$

In conclusion, isotretinoin is an effective agent to acne therapy and patient who use topical, oral or systemic retinoids should be monitored for its bone marrow effects. the clinical response in a multiple-dose trial. J Am Acad Dermatol 1980;3: 602-11.

5. Shahidullah M. Isotretinoin therapy in acne vulgaris: A 10-year retrospective study in Singapore. Int J Dermatol 1994;33: 60-3.

6. Reynolds CP. Differentiating agents in pediatric malignancies: retinoids in neuroblastoma. Curr Oncol Rep 2000;2: 511-8.

7. Palumbo $A$, Battaglio $S$, Napoli $P$, Bruno $B$, Omedè $P$, Boccadoro $M$, Pileri A. Retinoic acid inhibits the growth of human myeloma cells in vitro. Br J Haematol 1995;89: 555-60.

8. Norris DA, Osborn R, Robinson W, Tonnesen MG. Isotretinoin produces significant inhibition of monocyte and neutrophil chemotaxis in vivo in patients with cystic acne. J Invest Dermatol 1987;89: 38-43.

9. Ozdemir MA, Kose M, Karakukcu M, Ferahbas A, Patiroglu T, Koklu E. Isotretinoin-induced agranulocytosis. Pediatr Dermatol 2007;24: 425-6.

10. Waisman M. Agranulocytosis from isotretinoids. J Am Acad Dermatol 1988;18(2 Pt 1): 395-6.

11. Friedman SJ. Leucopenia and neutropenia associated with isotretinoin therapy. Arch Dermatol 1987;123: 293-5.

\section{REFERENCES}

1. Thiboutot DM. Overview of acne and its treatment. Cutis 2008;81(1 Suppl): 3-7.

2. Orfanos $\mathrm{CE}$, Bauer R. Evidence for anti-inflammatory activities of oral synthetic retinoids: experimental findings and clinical experience. $\mathrm{Br}$ J Dermatol 1983;109 Suppl 25: 55-60.

3. Bérard A, Azoulay L, Koren G, Blais L, Perreault S, Oraichi D. Isotretinoin, pregnancies, abortions and birth defects: a populationbased perspective. Brit J Clin Pharmacol 2007;63: 196-205.

4. Farrell LN, Strauss JS, Straniere AM. The treatment of severe cystic acne with 13-cis-retinoic acid: evaluation of sebum production and 